\title{
Factors Affecting Milk Production in Anatolian Buffalo Herds in Samsun Province of Turkey
}

\author{
Ercan Bayram ${ }^{1, a}$, Savaş Atasever ${ }^{1, b, *}$ \\ ${ }^{I}$ Department of Animal Science, Faculty of Agriculture, University of Ondokuz Mayls, 55139 Atakum/Samsun, Turkey \\ *Corresponding author

\begin{tabular}{l|l}
\hline A R T I C L E I N F O & A B S T R A C T \\
\hline Research Article & $\begin{array}{l}\text { The aim of this study was to determine the relations of some affecting factors with milk production } \\
\text { in Anatolian buffalo enterprises in Samsun province, Turkey. The questionnaires were applied by } \\
\text { interviews to thirty nine buffalo farmers those selected by random sampling method. Effects of } \\
\text { experience (EF) and education level (EL) of farmer, number of milking animal (NM), concentrate } \\
\text { feeding application (CF), weaning period (WP), milking frequency per day (MP), udder disinfection } \\
\text { premilking (UDP) on daily milk yield (DMY) were found to be insignificant. Further studies } \\
\text { including more factors and data might be suggested to reveal detailed information between farm } \\
\text { practices and milk production in water buffaloes. }\end{array}$ \\
$\begin{array}{l}\text { Received : 12/02/2020 } \\
\text { Accepted : 12/04/2020 }\end{array}$
\end{tabular}

Keywords:

Buffalo

Husbandry

Environmental factor

Herd management

Milk production

ercanbayram_@hotmail.com (iD) https://orcid.org/0000-0002-7456-3813

b@satasev@omu.edu.tr

https://orcid.org/0000-0002-0288-6197

(c) (1) ) This work is licensed under Creative Commons Attribution 4.0 International License

\section{Introduction}

Trend on organic animal production is tended to elevation as an important line in many countries. Related to organic farming, water buffalo that serve milk, beef and draught yield has seventy four different breeds (Sarızkan, 2011). In general, this specie ensure a marked income especially for poor people, however, watery pasture and land of the animals have recently restricted. Buffalo beef carries an important advantage by ingredient when compared to bovine beef. For instance, $100 \mathrm{~g}$ buffalo beef has $1.8 \mathrm{~g}$ fat, $26.8 \mathrm{~g}$ protein, $21 \mathrm{~g}$ vitamin and $641.8 \mathrm{mg}$ mineral (Atasever and Erdem, 2008; Soysal, 2009), lesser cholesterol and fat, and more protein and mineral in comparison to bovine beef. Besides, obtained raw milk is generally used to produce butterfly, cream and yoghurt. In Turkey conditions, water buffalo raising has been maintained as tradional-family type and grazing has been continued by a common herdsman on a shared pasture. Nevertheless, in the Black Sea region, farmers bring their herd to the pasture area every morning and return them to the barns in the evening, also, keep all animals within the barns during the winter (Soysal, 2009). In the district basis,
Bafra of Samsun province has the most water buffalo population in the region. The district has a rich habitat by watery land, pasture, lake or swamp areas. Of these, Kizilirmak Delta is one of the suitable facility to keep water buffaloes. The delta has 16 thousand ha watery area and is located into Alacam, Ondokuzmayis and Yakakent districts. With this side, the delta is known as the unique location by biodiversity. In the area, Anatolian buffaloes utilized from delta resources and help to wild life around the district. In spite of some studies on water buffalo raising have been performed in Turkey (Demir and Akbulut, 2016; Isik and Gul, 2016; Ermetin, 2017), most of the studies focused on only determining the general status of the farms. Whereas, revealing the association of effective factors related to the farm management with milk production level will provide a marked benefit for animal production of the region and the country.

The objective of the current study was to determine the relations of effective factors with milk yield in Anatolian buffaloes reared in Samsun province, Turkey. 


\section{Materials and Methods}

A total of 395 buffalo farms those had $5 \leq$ milking animals per farm within the 1325 enterprises in Samsun province in 2014. With random sampling method, 33 actual and 6 reserve farms had been recorded for survey. Questionnaires were applied to farm owners as face to face and obtained data were evaluated. Daily milk yield (DMY) per milking animal was noted from the records of the farms. The forms were included experience (EF) and education level of farmer (EL), number of milking animal (NM), concentrate feeding application (CF), weaning period (WP), milking frequency per day (MF) and udder disinfection premilking (UDP). The effects of EF, EL and NM on DMY were tested by One-Way ANOVA and group differences was analyzed using Duncan's multiple range test. To analyses, three subgroups were divided for the environment factors (for EF; $1=\leq 10,2=11-25$ and $3=>25$ years, for EL; 1=illiterate, 2=primary-secondary and $3=$ high education, for NM; $1=1-5,2=6-9$ and $3=>10$ heads). The linear model was as follows:

$$
\mathrm{Y}_{\mathrm{ijklm}}=\mu+\mathrm{a}_{\mathrm{i}}+\mathrm{b}_{\mathrm{j}}+\mathrm{c}_{\mathrm{k}}+\mathrm{d}_{\mathrm{l}}+\mathrm{e}_{\mathrm{ijklm}}
$$

Where;

$Y_{\mathrm{ijkl}}=$ observation value, $\mu=$ mean of the population, $\mathrm{a}_{\mathrm{i}}=$ effect of EF (i=1,2,3), $b_{j}=$ effect of EL (i=1,2,3), $c_{k}=$ effect of $\mathrm{NM}(\mathrm{k}=1,2,3), \mathrm{e}_{\mathrm{ijk} \mathrm{k}}=$ random error. The effects of other factors were analyzed by independent simple $t$-test. All statistical test were performed by SPSS 17 at the 0.05 significance level.

\section{Results and Discussion}

In Table 1, the means of DMY according to districts of Samsun province were given. Relatively high number of the farms and higher milk production in Bafra is attractive. This case points out to the suitable localization of this region for water buffalo raising. Really, Selcuk (2012) declared that the Kizilirmak Delta is an unique habitat for Anatolian Buffaloes and this area ensures an important average for the farmers to keep and raise this species.

The means of the investigated items are shown in Table 2. As seen, no statistical difference was calculated among the subgroups. In this research, DMY of the buffaloes of the farmers with experience $>25 \mathrm{y}$ was higher up to $18.66 \%$ when compared to first group with 1-10 y. Estimated insignificant value by statistic might be caused by unequal sample size of the subgroups. In a study conducted on dairy farms by Ozkan and Erkus (2003), the mean of the breeders was calculated to be $47 \mathrm{y}$ and no person was determined below 30 y. Ozcatalbas et al. (2010) analysed the socioeconomic factors in dairy farms of Antalya province of Turkey and they revealed an association of experience with DMY. Besides, Atasever et al. (2015) also determined no statistical difference among experience groups occurred by dairy farm owners. As it is understood, experience of the farm owner might be expected a positive case on the milk production in dairy animals. At this point, further studies including more sample size may be suggested.

Table 2 also shows the DMY of the animals according to education level (EL) of farmer. It can be understood that an important percentage of the farmers had relatively low
EL. From this point of the view, water buffalo breeding has mostly been preferred by the farmers with lower EL. The findings determined here were found to be parallel with the results of many studies (Bars and Akbay, 2013; Boz, 2013; Unalan et al., 2013; Demir et al, 2014a) those conducted in Turkey conditions. In spite of insignificant difference was noted among three EL groups in Table 2, markedly reduction in DMY of the animals of the farmers with illiterate was assessed to be a striking result. At this context, encouraging the farmers with relatively high EL might be seen a positive approach to reach more milk production in the herds.

Table 1. DMY means by the districts of Samsun

\begin{tabular}{l|cc}
\hline \multicolumn{1}{c|}{ District } & $\mathrm{n}$ & $\mathrm{DMY} \pm \mathrm{SD}(\mathrm{kg})$ \\
\hline Bafra & 14 & $3.303 \pm 1.144$ \\
Terme & 7 & $2.571 \pm 0.975$ \\
Alacam & 8 & $2.593 \pm 0.680$ \\
Carsamba & 5 & $2.600 \pm 1.083$ \\
Ondokuz Mayis & 5 & $2.100 \pm 1.140$ \\
\hline General & 39 & $2.782 \pm 1.060$ \\
\hline
\end{tabular}

Table 2. DMY means by effective factors

\begin{tabular}{|c|c|c|}
\hline Factors & $\mathrm{n}$ & $\mathrm{DMY} \pm \mathrm{SD}$ \\
\hline \multicolumn{3}{|c|}{ Experience of farmer (year) } \\
\hline $1-10$ & 8 & $2.375 \pm 1.217$ \\
\hline $11-25$ & 9 & $2.805 \pm 0.747$ \\
\hline$>25$ & 22 & $2.920 \pm 1.116$ \\
\hline \multicolumn{3}{|c|}{ Education level of farmer } \\
\hline Illiterate & 6 & $2.167 \pm 0.683$ \\
\hline Primary-Secondary & 26 & $2.904 \pm 1.120$ \\
\hline High & 7 & $2.857 \pm 1.029$ \\
\hline \multicolumn{3}{|c|}{ Number of milking buffalo } \\
\hline $1-5$ & 14 & $2.607 \pm 1.022$ \\
\hline $6-9$ & 15 & $2.683 \pm 0.837$ \\
\hline$\geq 10$ & 10 & $3.175 \pm 1.384$ \\
\hline \multicolumn{3}{|c|}{ Concentrate feeding } \\
\hline Yes & 33 & $2.795 \pm 1.171$ \\
\hline No & 6 & $2.541 \pm 0.318$ \\
\hline \multicolumn{3}{|c|}{ Weaning period $(\mathrm{d})$} \\
\hline$<204$ & 24 & $2.833 \pm 1.017$ \\
\hline$\geq 204$ & 11 & $2.409 \pm 1.215$ \\
\hline \multicolumn{3}{|c|}{ Daily milking frequency } \\
\hline 1 & 27 & $2.592 \pm 0.968$ \\
\hline 2 & 12 & $3.208 \pm 1.176$ \\
\hline \multicolumn{3}{|c|}{ Udder disinfection premilking } \\
\hline Yes & 32 & $2.859 \pm 1.054$ \\
\hline No & 7 & $2.428 \pm 1.096$ \\
\hline Overall & 39 & $2.782 \pm 1.060$ \\
\hline
\end{tabular}

Effects of number of milking buffalo (NMB) on DMY was also investigated (Table 2). While the highest DMY $(3.175 \pm 1.384 \mathrm{~kg})$ was gained from the farms with highest NMB, DMY means were not differed by the NMB groups. However, calculated mean of NMG (8.38 head/farm) was lower than the NMB of the farms noted by Isik and Gul (2016) in Mus province conditions.

In the study, it was noted that the buffaloes kept between September and December in a high percentage $(93.3 \%)$ of the evaluated farms. The farmers those used concentrate feed (CF) in that period was calculated as $84.6 \%$ (Table 2). In the farms where concentrate used, 
milking buffaloes had about $9.08 \%$ more DMY in comparison to ones kept in the farms with no concentrate served. Nevertheless, this difference determined here was not found as statistically significant. Actually, the general concept in dairy farming that outcomes related to feed play a major role in farm economy. However, serving CF to the milking animals at least four months might be seen a favorable application to enhance milk production (Lawrence et al., 2015).

The mean of the WP (204 d) was based to divide the subgroups by this factor. This period was evaluated to be lengthy. Also, herds with shorter weaning period had $14.96 \%$ more DMY when compared to second group (Table 2). However, this difference was not found to be statistically significant. At this point, investigating this case using different WP means and more data might be suggested to obtain clearer results.

In the region, a great portion of the farmers milked their animals once a day. Relatively low milk production per milking buffalo might be caused to this case. Boujenane (2019) reported that elevated milking frequency stimulates milk production amount. Really, calculated $19.20 \%$ more milk per animal supported this concept, but this difference was found as insignificant.

Distribution of subgroups according to UDP is presented in Table 2. While animals where UDP applied had approximately $15.07 \%$ more DMY when compared to the others, this difference was not found to be significant. Also, a high portion of the breeders $(82.05 \%)$ applied UDP for the milking animals. Napolitano et al. (2005) emphasized the close association of hygienic status of the animals and production level. In a general evaluation, ensuring udder hygiene in the most farms of the current study might be seen a positive management practice. Gibson et al. (2008) pointed out that premilking udder cleaning is a considerable practice within the management processes. Besides, obtained findings here were found as preferable from the results of Millogo et al. (2008) and Demir et al. (2014b), and similar to the results of Wangdi et al. (2004) and Boz (2013).

In the present study, farm owners declared that raw milk has been sold in local bazaars $(35.9 \%)$, consumed by household $(30.5 \%)$ and processed to milk products $(28.2 \%)$. These options were found as inconsistent with the findings of Demir et al. (2014a) who conducted a survey on dairy farms of Kars province of Turkey. At this point, processing milk might be seen as the more profitable approach to boost income of the farms. A high potential of the consumers for buffalo cheese and yoghurt presents a favorable case to buffalo milk producers in the region. Also, the most important diseases threating animals were noted as the liver problems (37.5\%), malaise (25\%) and calving disorders $(12.5 \%)$. The first two problems bring to mind a complication related to drinking water served to the animals. Especially, intensively rice agriculture in the region might be caused to these cases by damaging groundwater via chemigation. In this context, new adjustments in the farm area including establishing artificial water supplies might be suggested to breeders in the location. Also, further researches focused on the causative factors and agents on these disorders should be conducted in the region.

\section{Conclusions}

In this study, some factors affecting milk production of Anatolian buffaloes reared in Samsun province were evaluated. It was concluded that experience of the farm owners were high, but education levels were low, relatively. While a high percent of the farms were smallscale ( $\leq 10$ milking animals), many farm owners served concentrate to the animals. The mean of the weaning period (204 d) was found as long. The daily milking frequency in the most farms $(69.23 \%)$ was once a day and udder cleaning before milking process was high $(82.05 \%)$ in the investigated farms. While no statistical difference was determined among the subgroups, further studies including more data might be suggested to reveal detailed information between farm applications and milk production in water buffaloes.

\section{Acknowledgements}

The present paper is based on a part of the master thesis of the first author. The authors thank to staff of Buffalo Breeders Association of Samsun Province for their helps and supports.

\section{References}

Atasever S, Erdem H. 2008. Water buffalo raising and its future in Turkey. Agric. Fac. OMU, 23 (1): 59-64.

Atasever S, Demiryurek K, Erdem H. 2015. Effects of some farm practices on milk production in dairy farms of Samsun province. J. Bahri Dagdas Anim. Res., 4 (2): 6-10.

Bars T, Akbay C. 2013. Structural analysis of milk and milk products industry in the province of Kahramanmaras. KSU J. Nat. Sci., 16 (2): 9-20.

Boujenane I. 2019. Effects of milking frequency on milk production and composition of Holstein cows during their first three lactations. Iran. J. Appl. Anim. Sci., 9(1), 25-29.

Boz I. 2013. Structure and problems of dairy farms in the Eastern Mediterranean region (Turkey). KSU J. Nat. Sci., 16 (1): 2432.

Demir P, Aral Y, Sariozkan S. 2014a. Socio-economic structure and production costs of dairy cattle farms in Kars province. Van Vet. J., 25 (1): 1 - 6.

Demir P, Işık Adıgüze, S, Sarı M, Ayvazoglu C. 2014b. The general structure and economic dimension of dairy cattle farms at central district in Kars province. F.U. Sag. Bil. Vet. Derg., 28: 9-13.

Demir Y, Akbulut O. 2016. Buffalo growing in Turkey and current situation in Erzurum province. East. Anatol. J. Sci., 2(2): 63-66.

Ermetin O. 2017. Husbandry and sustainability of water buffaloes in Turkey. Turk. J. Agric. Food Sci. Tech., 5(12): 1673-1682.

Gibson H, Sinclair LA, Brizuela CM, Worton H., Protheroe RG. 2008. Effectiveness of selected premilking teat-cleaning regimes in reducing teat microbial load on commercial dairy farms. Lett. Appl. Microbiol., 46: 295-300.

Isik M, Gul M. 2016. Economic and social structures of water buffalo farming in Mus province of Turkey. R. Bras. Zootec., 45(7):400-408

Lawrence DC, O'Donovan M, Boland TM, Lewis E, Kennedy E, 2015. The effect of concentrate feeding amount and feeding strategy on milk production, dry matter intake, and energy partitioning of autumn-calving Holstein-Friesian cows, J. Dairy Sci., 98, 338-348. 
Millogo V, Ouedraogo GA, Agenas S, Svennertsen-Sjaunja K. 2008. Survey dairy cattle milk production and milk quality problems in peri-urban areas in Burkina Faso, Afr. J. Agric. Res., 3: 215-224.

Napolitano F, Grasso F, Bordi A, Tripaldi C, Saltalamacchia F, Pacelli C, De Rosa G. 2005. On-farm welfare assessment in dairy cattle and buffaloes: evaluation of some animal-based parameters, Ital. J. Anim. Sci., 4: 223-231.

Ozcatalbas O, Akcaoz H, Firat MZ, Kutlar I. 2010. The analysis of sosyo-economic factors in dairy farming of Antalya province of Turkey, J. Anim. Vet. Adv., 9: 20-26.

Ozkan U, Erkus A. 2003. Economic analysis of cattle fattening farms in Bayburt province. Tar. Bil. Derg., 9(4):467-472.
Sariozkan S. 2011. The importance of water buffalo breeding in Turkey. Kafkas Univ. Vet. Fak. Derg., 17 (1): 163-166.

Selcuk Z. 2012. The Kizılırmak Delta: the natural habitat of Anatolian water buffaloes. Kafkas Univ. Vet. Fak. Derg., 18 (1): 167-168.

Soysal I. 2009. Buffalo Products and Production. Lesson Notes, 237 p., Tekirdag, Turkey.

Unalan A, Serbester U, Cinar M, Ceyhan A, Akyol E, Sekeroglu A, Erdem T, Y1lmaz S. 2013. The current status, main problems and solutions of dairy cattle farms in Niğde. Turkish Journal of Agriculture - Food Science and Technology, 1: 6772.

Wangdi J, Bhujel P, Timsina MP, Wangchuk S. 2014. Performance of Buffalo (Bubalusbubalis) under Bhutanese conditions, Global J. Dairy Farm. Milk Prod., 2:67-73. 